\title{
The Effects of Voluntary Disclosure and Dividend Propensity on Prices Leading Earnings
}

\author{
Khaled Hussainey and Martin Walker*
}

* Khaled Hussainey is based at Stirling University; Martin Walker is based at Manchester University. We have received helpful comments from David Stopforth, Thomas Schleicher, participants at the 2006 EAA and the 2006 BAA conferences and seminar participants at Glasgow and Hull Universities. We are grateful to the editor and two anonymous referees for helpful comments. We appreciate financial support from the ESRC (Grant Number RES-00023-0962). Correspondence should be addressed to Dr. Khaled Hussainey, Division of Accounting \& Finance, Stirling Management School, University of Stirling, Stirling FK9 4LA, UK. Email: Khaled.Hussainey@stir.ac.uk. 


\title{
The Effects of Voluntary Disclosure and Dividend Propensity on Prices Leading Earnings
}

\begin{abstract}
We investigate the joint effects of dividend propensity (i.e. whether a firm pays cash dividends) and voluntary disclosure on the relation between current stock returns and future earnings. We examine whether dividend propensity and voluntary disclosure act as substitutes or complements in the financial communication process. We also examine whether the effects of dividend propensity and voluntary disclosure vary between high and low growth firms.

Consistent with prior studies, we find that share price anticipation of earnings improves with increasing levels of annual report narrative disclosure, and that firms that pay dividends exhibit higher levels of share price anticipation of earnings than non-dividend-paying firms.

The paper adds to the literature on share price anticipation of earnings in two crucial respects. First we show that the associations of voluntary disclosure and dividend propensity with share price anticipation of earnings are statistically significant for high growth firms and insignificant for low growth firms. Second we show that the significant effects we find for dividend propensity and voluntary disclosure in high growth firms are not perfectly additive.
\end{abstract}




\section{Introduction}

Considerable attention has been given to examining the association between corporate disclosure and share price anticipation of earnings (e.g. Schleicher and Walker, 1999; Lundholm and Myers, 2002; Gelb and Zarowin, 2002; Hussainey et al., 2003 and Schleicher et al., 2007). These papers find that the stock market's ability to anticipate future earnings changes is significantly improved when firms voluntarily provide higher levels of disclosure. However, these studies do not take into account the possibility that dividend policy may provide an alternative device for conveying value relevant information to the stock market that might act as a substitute or complement for narrative disclosure in the financial communication process.

Hanlon et al. (2007) examine the impact of dividend propensity (i.e. whether a firm pays cash dividends) on the stock market's ability to anticipate future earnings. They modify and use the returns-earnings regression model introduced by Collins et al. (1994) to compare the association between current year stock returns and future earnings for firms that pay dividends in the current year as compared with non-dividend-paying firms. They find that US dividend-paying firms exhibit significantly higher levels of share price anticipation of earnings than non-dividendpaying firms. In addition, Hanlon et al. (2007) control for disclosure quality, as measured by AIMR-FAF scores, and they find that the significance of the dividend policy for anticipating future earnings is reduced. This suggests that dividends and disclosure might be substitute forms of financial communication. However, it is possible that the relative information content of dividends and voluntary disclosure could be different in the US than in the UK as the number of UK dividend-paying firms is greater than US dividend-paying firms in the period of 1996-2002 
(73 per cent in the UK compared with 23 per cent in the US; see Denis and Osobov, 2008 for more details). ${ }^{1}$

The present paper examines the joint effects of dividend propensity and voluntary disclosure on share price anticipation of earnings.

In undertaking this task, we argue that it is vital to take into account the growth characteristics of firms. There are strong theoretical and empirical grounds for expecting this to be the case. Several researchers (see for example; Brown et al., 1999, Francis and Schipper, 1999 and Lev, 1989) have identified a number of problems with the financial reporting process, instances of accounting 'failure'. Particular attention has been paid to the inability of the financial reporting system to capture the value relevance of intangible investments on a timely basis (see for example; Amir and Lev, 1996; Lev, 2001 and Lev and Sougiannis, 1996). High growth and intangible asset intensity are factors that tend to reduce the predictive value of current earnings for future earnings. Investors of high growth firms are aware that current earnings provide a poor guide to the future financial performance of the firm. Thus, when valuing these firms, investors tend to seek other, more-timely, predictors of future earnings beyond current earnings.

In this paper we use the future earnings response model of Collins et al. (1994) to measure the degree of share price anticipation of earnings. We test to see if the level of share price anticipation of earnings varies with dividend propensity and with the level of voluntary

\footnotetext{
1 One possible reason for this is the difference between the treatments of dividend income in the two countries (Morgan and Thomas, 1998). In particular, the UK imputation system up to 5 April 1997 significantly favours dividend payments compared to the US for both individuals and pension funds and thereafter still favours dividend payments to individuals. The abolition of advance corporation tax in April 1999 did not offer this (Bank et al., 2006). Oswald and Young (2008:51-2) provide detailed information on dividends and UK tax legislations.
} 
disclosure. We also test whether the associations between dividend propensity or voluntary disclosure and share price anticipation of earnings differ between high and low growth firms.

Our results show that both narrative disclosure level and dividend propensity are associated with significantly improved share price anticipation of earnings for high growth firms. Moreover, for high growth firms, narrative disclosure and dividend propensity appear, to some extent, to be substitute forms of financial communication. In contrast we find that neither narrative disclosure level nor dividend propensity exhibit significant association with share price anticipation of earnings for low growth firms.

Thus the paper makes an important and novel contribution to the literature on corporate financial communication. So far as we are aware it is the only paper to examine the joint role of narrative disclosure and dividend propensity on prices leading earnings. Moreover it is the first paper to show that the predictive value of dividend propensity and narrative disclosure is sensitive to the growth characteristics of the firm.

The paper proceeds as follows. Section 2 reviews the prior literature and develops our hypotheses. In Section 3, we describe the generation of our disclosures scores. Our measure of share price anticipation of earnings is discussed in Section 4. Section 5 describes the data and we present our main regression results in Section 6. Section 7 presents our specification check and Section 8 concludes and suggests areas for future research. 


\section{Prior research and hypotheses development}

\subsection{Disclosure and Prices Leading Earnings}

There is a growing body of literature which examines how corporate disclosures affect the stock market's ability to anticipate future earnings changes. Hussainey et al. (2003) examine the information content of annual report narrative sections for anticipating future earnings for UK firms. Their work builds on the earlier work of Schleicher and Walker (1999) but, by adopting the augmented returns-earnings regression model of Collins et al. (1994), uses a research design closer to those used in Gelb and Zarowin (2002) and Lundholm and Myers (2002).

Hussainey et al. (2003) and Schleicher and Walker (1999) find that improved levels of annual report disclosures tend to lead to higher levels of share price anticipation of earnings. In particular, Hussainey et al. (2003) find that forward-looking earnings statements in the annual report narratives increase the market's ability to anticipate future earnings change. However, they do not find significant results when using a disclosure metric based on all types of forwardlooking statements. Gelb and Zarowin (2002) and Lundholm and Myers (2002) find that the quality of corporate disclosure, as measured by AIMR-FAF analysts' rankings of disclosure, is positively associated with the market's ability to anticipate future earnings changes. Schleicher et al. (2007) find that the association between levels of annual report disclosures and share price anticipation of earnings is not the same for profitable and unprofitable firms. They find that the ability of stock returns to anticipate next period's earnings change is significantly greater for unprofitable firms that provide higher levels of earnings predictions in their annual report narratives. They did not find such results for profitable firms. 
None of the above papers makes any distinction between high growth firms and low growth firms. However all of these studies make use of the relation between current and future earnings and stock returns to assess the information content of corporate disclosures. Moreover it is well known that differences in growth rates cause the association between stock returns and contemporaneous earnings changes to vary between firms (Collins and Kothari, 1989 and Rayburn, 1986). High growth firms tend to have higher levels of intangible assets (Thornhill and Gellatly, 2005). Such intangible assets tend to reduce the value relevance of current earnings for overall firm value. If the benefits from these assets are uncertain, investors will find it more difficult to appraise firm value (Kothari et al., 2002). Additionally, Lee et al. (2005) argue that increasing uncertainty about future benefits will lead to more information asymmetry between investors and managers and may introduce noise in the estimation of firm value in high-tech in comparison with low-tech firms. ${ }^{2}$ Firms can reduce such information asymmetry by providing additional voluntary information (Ertimur, 2004). In this paper, we ask whether increasing the level of annual report forward-looking disclosures improves the stock market's ability to anticipate future earnings changes, especially for high growth firms.

While no papers have examined the effect of firm specific growth characteristics on the association between disclosure and the stock market's ability to anticipate future earnings changes, possibly the most closely related paper to ours is Kwon (2002). Kwon (2002) compares analysts' forecast accuracy and dispersion between high-tech and low-tech firms. He finds that high-tech firms have lower error and dispersion of analyst earnings forecasts than low-tech firms. In addition, he finds that high-tech firms have higher analyst forecast accuracy than low-tech

\footnotetext{
${ }^{2}$ High tech firms invest more in unrecognised intangible assets (Kwon, 2002). As a consequence our high growth sample contains a much larger proportion of high tech firms than the low growth sample.
} 
firms. He attributes this finding to differences in the level of voluntary disclosure provided by these firms. In particular, he states that high-tech firms increase their levels of voluntary disclosure to attract more analysts. Increasing disclosure leads to higher levels of analyst forecast accuracy and lower levels of forecast dispersion. The finding of Kwon's paper is important in relation to ours as it indicates that firm characteristics such as growth prospects can condition the forecasting practices of stock market participants.

Considerable attention has been paid to the inability of financial performance measures to capture the value relevance of intangible investments on a timely basis (see Abdolmohammadi et al., 2006; Lee, et al, 2005; Lev, 2001; Lev and Zarowin, 1999). As a consequence the predictive value of current earnings for future earnings is lower for intangibles rich high growth firms than for low growth firms.

Given the limited usefulness of their current earnings for predicting future earnings, one possible response for firms with significant unrecognised intangible assets or high growth prospects is to make voluntary disclosure in order to convey value relevant information in a more timely way (Gelb, 2002, Hyytinen and Pajarinen, 2005 and Khurana et al., 2006). Moreover, since current earnings provide a better basis for predicting future earnings for low growth firm, we expect the influence of disclosure on the relation between current returns and future earnings to be stronger for high growth firms than low growth firms.

The following hypotheses focus on how voluntary disclosure affects the stock market's ability to anticipate future earnings:

H1 The degree of share price anticipation of earnings is positively related to the level of voluntary disclosure. 
H2 The degree of share price anticipation of earnings is positively related to the level of voluntary disclosure for high growth firms.

H3 The degree of share price anticipation of earnings is positively related to the level of voluntary disclosure for low growth firms.

We also compare the effect of voluntary disclosure between high and low growth firms. Thus, the fourth hypothesis states:

H4 The strength of the degree of association between share price anticipation of earnings and voluntary disclosure is greater for high growth firms than for low growth firms.

\subsection{Dividends and prices leading earnings}

Apart from the audited financial statements, voluntary disclosure is one of two main ways that firms can communicate information about future earnings to the stock market. The other way is through some types of financial policy choices.

There is a vast literature that explores the possibility that financial policy choices may serve to convey information to the market. One such line of argument focuses on financial signalling as a solution to the adverse selection problem. In this paper we focus on one particular form of financial signalling, cash dividends. There is a substantial literature on dividend signalling in its various forms. This literature has produced a complex set of models that can be used to rationalise alternative types of dividend signalling behaviour, that can represent different forms of dividend policy, and that generate different models of the relation between company cash flows, dividends, and share prices (see Allen and Michaely, 2003; Benartzi et al., 1997; Eades, 1982; and Grullon et al., 2003 for surveys). 
Another line of argument focuses on financial policy choices as a part of the solution to investor/manager agency conflicts. For example, Jensen (1986) points to the potential agency costs of firms having very high free cash flows, and the need to set limits to the discretionary investment choices of company managers. Under this line of reasoning, the payment of dividends is potentially informative about the quality of external investor protection in the firm. Note that under this line of reasoning, the communication of information is incidental to the governance role of dividends.

Some recent studies explore the nature of the information revealed by dividends (i.e.; Grullon et al., 2002 and Nam et al., 2008). These studies suggest that dividends changes are associated with changes in firm risk. In particular, Nam et al. (2008) show that firms that initiate dividend payment experience a reduction in risk, and Grullon et al. (2002) show that firms that increase their payout ratios experience reduced risk.

A number of papers have studied the empirical links between earnings quality (in particular earnings persistence) and dividend payouts. The recent papers of Garcia-Borbolla et al. (2004) and Skinner (2004) identify subtle and complex interactions between dividend propensity and the quality of earnings. Moreover these studies reveal significant differences between US and European firms. Skinner's study suggests that dividends are more likely to be paid by the larger, more stable US firms. Such firms tend to have more predictable earnings streams. Thus his work suggests that the predictability of earnings from current earnings and the payment of dividends are mutually related through the underlying stability of the firm. On the other hand the study by Garcia-Borbolla et al. of European firms concludes that dividends are more useful for predicting future earnings where the quality of earnings is low. 
This paper makes no attempt to identify the specific types of information that dividend payments convey to investors. As in Hanlon et al. (2007) we simply start from the observation that not all firms pay dividends. Firms that do not pay dividends, by definition, cannot be using dividends to communicate value relevant information. On the other hand the payment of dividends may change the ability of the market to anticipate future earnings changes.

Relative to Hanlon et al. we make three contributions. First we present results for the UK economy for a period in which the propensity to pay dividends was much higher than in the US. The average dividend propensity for the firms in our sample is $84 \%$, considerably higher than the corresponding propensity for US firms. For example Skinner (2008) reports an average dividend propensity of $28 \%$ for US listed firms for the years 1995 to 2004 . Second, we jointly model the effects of voluntary disclosure and dividend propensity on share price anticipation of earnings. Third, we model the extent to which the effects of dividend propensity and voluntary disclosure on share price anticipation of earnings are linked to the growth characteristics of firms.

Hanlon et al. (2007) make no distinction between high and low growth firms. However it can be argued that the importance of other information for predicting future earnings could differ between high and low growth situations. High growth firms typically exhibit higher levels of information asymmetry than low growth firms, and high growth firms are more likely to need to raise external capital in order to finance their dividend payments whilst maintaining high levels of investments. Thus there are good reasons to expect the effects of voluntary disclosure and dividend propensity to vary between high and low growth firms.

Thus we state the following hypotheses: 
H5 The degree of share price anticipation of earnings is greater for dividend-paying firms than for non-dividend-paying firms.

H6 The degree of share price anticipation of earnings is greater for dividend-paying high growth firms than non-dividend-paying high growth firms.

H7 The degree of share price anticipation of earnings is greater for dividend-paying low growth firms than non-dividend-paying low growth firms.

H8 The strength of the degree of association between share price anticipation of earnings and dividend propensity is greater for high growth firms than low growth firms.

\subsection{The joint effect of disclosure and dividends on prices leading earnings}

Having introduced the main hypotheses relating to share price anticipation of earnings and the two forms of financial communication we now consider how to test whether the two forms of communication act as complements or substitutes. There are four logical possibilities:

First, if voluntary disclosure and dividend payments are different ways of conveying the same information, then firms that have high levels of disclosure but pay no dividends, should exhibit roughly the same degree of share price anticipation of earnings as firms with high levels of disclosure that pay dividends. Similarly firms that pay dividends should have roughly the same level of share price anticipation of earnings irrespective of their level of disclosure.

Second, if dividend payments and voluntary disclosure convey unrelated types of information then the level of share price anticipation of earnings for firms that have high levels of disclosure and pay dividends should be stronger than the level of share price anticipation of earnings for 
firms that have high levels of disclosure but do not pay dividends. Similarly, the level of share price anticipation of earnings should be stronger when both types of communication are present than when only the payment of dividends is present.

Third, if the combination of dividend payments and voluntary disclosure produces related information that is 'reinforcing' (i.e. if there is a multiplicative effect) then share price anticipation of earnings will be the greatest for firms that have high disclosure and also pay dividends.

Finally, if dividend payments and voluntary disclosure convey related information, but some of the information is common to both i.e. 'partially additive', then the level of share price anticipation of earnings for firms that have high levels of disclosure and pay dividends should be higher than the level of share price anticipation of earnings when firms have high levels of disclosure but do not pay dividends or the level of share price anticipation of earnings should be higher when both types of communications are present than when only the payment of dividends is present. We test to see which of these four possibilities is present in the data by allowing for an interactive effect in our model. Thus we state the following hypotheses:

H9 The effects of voluntary disclosure and dividend propensity on the degree of share price anticipation of earnings are additive.

H10 The effects of voluntary disclosure and dividend propensity on the degree of share price anticipation of earnings for high growth firms are additive.

H11 The effects of voluntary disclosure and dividend propensity on the degree of share price anticipation of earnings for low growth firms are additive. 
H12 The strength of the joint effect of disclosure and dividend propensity on share price anticipation of earnings is the same for high growth firms and low growth firms.

To test the above hypotheses, we follow the approach of Hussainey et al. (2003) to automate the generation of forward-looking earnings disclosure scores. Section 3 provides further details. We use the modified regression model of Collins et al. (1994) to measure the influence of voluntary disclosure and dividend propensity on share price anticipation of earnings. This model is discussed in Section 4.

\section{Disclosure scores}

We adopt the scoring methodology developed in Hussainey et al. (2003). They automate the generation of disclosure scores for large samples of UK firms through the use of QSR N6, a text analysis software package. ${ }^{3}$ We focus on annual report narratives because they are more likely to contain voluntary forward-looking earnings predictions than other sections of the annual report. We choose narrative sections with at least one of the following headings: Financial Highlights, Summary Results, Chairman's Statement, Chief Executive Officer's Review, Operating and Financial Review, Financial Review, Financial Director's Report, Finance Review, Business Review, and Operating Review. All other sections of the annual report are excluded from our analysis (for more details, see Hussainey et al., 2003).

To measure the informativeness of a firm's narrative disclosures, we identify the forward-looking earnings sentences that are most likely to be useful for predicting a firm's future earnings changes. Our measure of disclosure quality is the number of forward looking sentences in the

\footnotetext{
3 In the current paper, we use QSR N6 to further facilitate the automation of text searches. Further information about QSR N6 is available online at http://www.qsinternational.com.
} 
annual report narratives that contain earnings indicators. We focus on earnings indicators because Hussainey et al. (2003) and Schleicher et al. (2007) find that these indicators improve the stock market's ability to anticipate future earnings change one year ahead.

We calculate our disclosure scores in three steps. The first step requires the identification of all sentences that are associated with forward-looking statements in annual report narratives. In this step, we text-search the narrative sections of annual reports using the list of forward-looking key words adopted in Hussainey et al. (2003: 277). This list includes the following thirty-five key words: accelerate, anticipate, await, coming (financial) year(s), coming months, confidence (or confident), convince, (current) financial year, envisage, estimate, eventual, expect, forecast, forthcoming, hope, intend (or intention), likely (or unlikely), look forward (or look ahead), next, novel, optimistic, outlook, planned (or planning), predict, prospect, remain, renew, scope for (or scope to), shall, shortly, should, soon, will, well placed (or well positioned), year(s) ahead. Similar to Hussainey et al. (2003) we also include future year numbers in the list of forwardlooking key words.

The next step in the generation of earnings disclosure scores is the identification of information items that are relevant to the capital market in assessing the firm's future earnings. Since the capital market's information set is unobservable, Hussainey et al. (2003) examine the contents of sell-side analysts' reports as a proxy for the market's view about the firm's disclosure quality. For each forward-looking statement in analysts' reports, they identify the key noun of that statement. For the purpose of the current paper, we use the same list adopted in Hussainey et al. (2003:280) that is related to earnings indicators. The list contains the following twelve key words benefit, breakeven, budget, contribution, earnings, eps, loss, margin, profit, profitability, return and trading. 
Finally, we use QSR N6 to count the number of sentences that include both at least one forwardlooking key word and at least one earnings indicator. This is done by finding the intersection of the key word search and the topic search.

\section{A measure of prices leading earnings}

Our measure of prices leading earnings is based on Collins et al. (1994). They use the future earnings response coefficient (FERC) as a proxy for the stock market's ability to anticipate future earnings. FERC is estimated by regressing current year stock returns on current and future annual earnings and returns plus control variables. The regression model of Collins et al. (1994) has been applied in a large number of recent papers e.g.; Banghøj and Plenborg, 2008; Dhiensiri et al., 2005; Ettredge et al., 2005; Gelb and Zarowin, 2002; Hanlon et al., 2007; Hussainey et al., 2003; Lee et al., 2007; Lundholm and Myers, 2002; Orpurt and Zang, 2006; Oswald and Zarowin, 2007; Schleicher et al., 2007 and Tucker and Zarowin, 2006. In effect the regression model of Collins et al. has become the standard technique for measuring prices leading earnings.

Collins et al. (1994) start by highlighting the poor empirical performance of the basic contemporaneous returns earnings regression.

$$
R_{t}=b_{0}+b_{1} X_{t}+u_{t}
$$

Where $R_{t}$ is the stock return for year $t . X_{t}$ is defined as earnings change deflated by price at $t-1$. Under ideal conditions ${ }^{4}$ equation (1) will yield a perfect fit, and the earnings response coefficient (ERC) will be equal to $\frac{1+r}{r}$, where $r$ is the required rate of return on equity (Walker,

\footnotetext{
${ }^{4}$ Walker (2004) argues that ideal conditions require semi-strong market efficiency. In such a market, earnings follow a random walk and earnings at time $t$ capture all value relevant information available at time $t$.
} 
2004). Numerous attempts to estimate equation (1) on annual data have revealed a very poor statistical fit (an $\mathrm{R}^{2}$ of $10 \%$ or less) and an ERC between 1 and 3 i.e. much lower than the value implied by a typical cost of equity capital.

Collins et al. (1994) argue that current returns reflect information about both current and future earnings. Therefore any attempt to explain current stock return in terms of earnings changes, should control for information about future earnings received in the current period. In the light of this argument, they include three future earnings growth variables $(\mathrm{N}=3$ and $\mathrm{k}=1,2,3)$ and make a number of adjustments to equation (1) to arrive at the following regression model ${ }^{5}$ :

$$
R_{t}=b_{0}+b_{1} X_{t}+\sum_{k=1}^{N} b_{k+1} X_{t+k}+\sum_{k=1}^{N} b_{k+N+1} R_{t+k}+b_{2 N+2} A G_{t}+b_{2 N+3} E P_{t-1}+e_{t}
$$

where:

$R_{t}$ is the stock return for year $t$.

$R_{t+1}, R_{t+2}$ and $R_{t+3}$ are the stock returns of years $t+1, t+2$ and $t+3$ respectively.

$X_{t}, X_{t+1}, X_{t+2}$ and $X_{t+3}$ are defined as earnings change deflated by lagged earnings at $t-1$.

$E P_{t-1}$ is earnings of period $t-1$ over price starting four months after the financial year-end of period $t-1$.

$A G_{t}$ is the growth rate of total book value of assets for period $t$.

\footnotetext{
${ }^{5}$ Note that Collins et al. (1994) find that the association between current stock returns and future earnings is not significant beyond three years ahead.
} 
Equation (2) shows that a number of forward dated variables are introduced in order to measure the level of prices leading earnings. Specifically, the model includes future earnings changes as proxies for the information received by the market in period $t$ about earnings growth in years $t+1$ and beyond. The inclusion of forward returns in the model, $R_{t+1}, R_{t+2}$ and $R_{t+3}$, controls for news about earnings growth in period $t+1, t+2, t+3$ received in period $t+1, t+2, t+3$ respectively. Because the forward returns variables control for news received in the future about future earnings, the forward earnings variables $X_{t+1}, X_{t+2}$ and $X_{t+3}$ proxy for news about future earnings received in the current period, $t$. This model includes the contemporaneous asset growth rate, $A G_{t}$ to control for the possibility that firms may invest in advance of future earnings. It also includes the earnings-price ratio, $E P_{t-1}$, to control for the possibility that the earnings of period $t-1$ are not a good proxy for the market's expectations (at time $t-1$ ) of the earnings for period $t$ and beyond.

For the ease of exposition we following Lundholm and Myers (2002) and Oswald and Zarowin (2007) idea in aggregating future earnings over three years into one future variable, $X_{t 3}$ and future returns over three years into one future variable, $R_{t 3} \cdot{ }^{6}$ Such aggregations produce the following regression model:

$$
R_{t}=b_{0}+b_{1} X_{t}+b_{2} X_{t 3}+b_{3} R_{t 3}+b_{4} A G_{t}+b_{5} E P_{t-1}+e_{t}
$$

To test our main hypotheses, we use the modified version of Collins et al. (1994), equation (3). However, similar to Hussainey et al. (2003) and Schleicher et al. (2007), in defining the earnings growth variable, we deflate earnings change by the share price at the start of the current year and

\footnotetext{
${ }^{6}$ Lundholm and Myers (2002) show that their results are unchanged whether the three future years are aggregated or separated.
} 
not by lagged earnings. This is due to the fact that it is difficult to define earnings growth when lagged earnings are negative or zero. As a result, a price deflator is used instead of the earnings deflator.

As argued earlier, current earnings numbers are likely to be less useful for predicting earnings for high growth firms. So we predict that these firms will use other indicators such as voluntary disclosure or dividend decisions to convey value relevant information in addition to current earnings. Such information should enable the market to better anticipate a firm's future earnings. This should lead to high voluntary disclosure firms or dividend-paying firms having a stronger relation between current returns and future earnings changes than low disclosure firms or nondividend-paying firms. Therefore, we predict higher FERCs for high disclosure firms or dividend-paying firms.

To test this prediction we interact all independent variables in equation (3) with a dummy variable, $D$, defined to be one for high disclosure firms and zero otherwise. We do not use the actual disclosure scores. Instead we define $D$ to be 1 for firms in the top two quartiles of the distribution of disclosure scores and 0 otherwise. ${ }^{7}$ We also interact all independent variables with a dummy variable, Div, defined to be one for firms that pay a dividend in the current year and zero otherwise. Finally we extend the model to test for the interaction between $D$ and Div. Interacting all explanatory variables in (3) with $D, D i v$, and $D^{*} D i v$ yields our main regression model:

\footnotetext{
${ }^{7}$ In Hussainey et al. (2003) and Gelb and Zarowin (2002), the authors drop observations with disclosure scores in the second and third quartiles. However, we use the full sample without dropping observations in the middle quartiles to maintain a usable sample size for the regression analyses. As we will discuss later, Table 1 Panel $\mathrm{C}$ shows that the number of usable non-dividend-paying firms is 551. This number comprises 297 high growth firm-years and 254 low growth firm-years. Deleting firms in the middle quartiles will significantly reduce the usable number of observations in each growth category (e.g.; the number will be 142 for high growth firms and 111 for low growth firms).
} 


$$
\begin{aligned}
& R_{t}=b_{0}+b_{1} X_{t}+b_{2} X_{t 3}+b_{3} R_{t 3}+b_{4} A G_{t}+b_{5} E P_{t-1} \\
& b_{6} D+b_{7} D^{*} X_{t}+b_{8} D^{*} X_{t 3}+b_{9} D^{*} R_{t 3}+b_{10} D^{*} A G_{t}+b_{11} D^{*} E P_{t-1} \\
& b_{12} D i v+b_{13} D i v^{*} X_{t}+b_{14} D i v^{*} X_{t 3}+b_{15} D i v^{*} R_{t 3}+b_{16} D i v^{*} A G_{t}+b_{17} D i v^{*} E P_{t-1} \\
& b_{18} D^{*} D i v+b_{19} D^{*} D i v^{*} X_{t}+b_{20} D^{*} D i v^{*} X_{t 3}+b_{21} D^{*} D i v^{*} R_{t 3}+b_{22} D^{*} D i v^{*} A G_{t}+b_{23} D^{*} D i v^{*} E P_{t-1}+e_{t}
\end{aligned}
$$

The coefficient on $X_{t}$ is hypothesised to be positive. The coefficient on $X_{t 3}$ measures three years ahead share price anticipation of earnings for non-dividend-paying firms with low disclosure scores. This is the base case in the model. All independent variables are interacted with both of the two dummy variables $D$ and $D i v$. The coefficient on $D^{*} X_{t 3}$ measures the extent to which share price anticipation of earnings is greater for high disclosure non-dividend-paying firms compared to the base case (i.e. it measures the pure disclosure effect). The coefficient on $D i v * X_{t 3}$ measures the extent to which share price anticipation of earnings is greater for low disclosure dividend-paying firms compared to the base case.

We expect the regression coefficients associated with $D^{*} X_{t 3}$ and $D i v * X_{t 3}$ to be significantly positive for high growth firms. In addition we expect these coefficients to be smaller for low growth firms than for high growth firms.

The variable $D^{*} D i v * X_{t 3}$ measures the incremental effect of both high disclosure and dividend propensity. There are four logical possibilities: ${ }^{8}$

First, both disclosure and dividends provide the same information. In this case the coefficient on $D * X_{t 3}$ will be equal to the coefficient on $D i v * X_{t 3}$. In addition, the coefficient on $D * D i v * X_{t 3}$ should be negative and equal in absolute value to the coefficients on $D^{*} X_{t 3}$ or $D i v * X_{t 3}$. As a result, the total impact of both disclosure and dividends should be calculated as follows:

\footnotetext{
${ }^{8}$ We thank an anonymous referee for the suggestion.
} 
$D * X_{t 3}+D i v * X_{t 3}+D * D i v * X_{t 3}=D * X_{t 3}\left(\right.$ or $=D i v * X_{t 3}$, since $\left.D * X_{t 3}=D i v * X_{t 3}\right)$.

Second, both types of communication provide ('additive') unrelated information. In this case we predict that the coefficient on $D * D i v * X_{t 3}$ should not be significantly different from zero. As a result, the total impact of both disclosure and dividends should be calculated as follows:

$D * X_{t 3}+D_{i v} * X_{t 3}-D * D i v * X_{t 3}=D * X_{t 3}+D i v * X_{t 3}$

Third, both types of communication provide related information that is 'reinforcing' or 'multiplicative'. In this case the coefficient on $D^{*} D i v^{*} X_{t 3}$ should be significantly greater than zero. In other word, the sum of the coefficients on $D^{*} X_{t 3}, D i v * X_{t 3}$ and $D^{*} D_{i v} * X_{t 3}$ should be significantly greater than the sum of the coefficients on $D * X_{t 3}$ and $D i v * X_{t 3}$. In this case, the inference is that both dividend propensity and voluntary disclosure are strictly complementary.

Finally both types of communication provide related information, but some of the information is common to both i.e. 'partially additive'. Therefore, we predict that the coefficient on $D^{*} D i v^{*} X_{t 3}$ should be significantly lesser than zero. In other word, the sum of the coefficients on $D^{*} X_{t 3}, \operatorname{Div}^{*} X_{t 3}$ and $D^{*} \operatorname{Div}^{*} X_{t 3}$ should be significantly lesser than the sum of the coefficients on $D * X_{t 3}$ and $D i v * X_{t 3}$. In this case, the inference is that both dividend propensity and voluntary disclosure are partial substitutes.

We treat the issue of which of these four logical possibilities is true as a purely empirical question and offer no prior theoretical predictions as to which of these outcomes is the most likely. 


\section{Data}

To perform our analyses, annual reports in an electronic format are required in order to use QSR N6 software as a text analysis tool. Therefore, our initial sample is limited to all UK nonfinancial firms on the Dialog database that have at least one annual report. Dialog covers large cross-sections of electronic non-financial UK annual reports for the years 1996 to 2002. So, we limit our study to that sample period. ${ }^{9}$ We use book-to-market value as a measure of growth. We measure growth on a yearly basis. This allows us to examine the effect of disclosure and dividends on share price anticipation of earnings when firms are classified as high growth or low growth in a particular time period. We identify high growth firms as those having below median levels of book-to-market value and low growth firms as those having above median levels of book-to-market value.

The total number of annual reports on Dialog for non-financial firms for the sample period is 8,098. Of those, 7,977 firm-years have matching records in Datastream. We delete 1312 firmyears observations because of changing year-ends. This leaves 6665 firm-years. We also delete 2958 firm-years missing observations. This leaves 3707 firm-year observations. Finally, we delete outliers defined as observations falling into the top or bottom one per cent of the distribution of any of the regression variables. Following Schleicher et al. (2007), we treat the observations of high and low growth firms as separate distributions. Otherwise, an unreasonably large number of high growth firm's observations will fall into the top and bottom one per cent. Deletion of inappropriate observations and observations with missing data reduces the sample to

\footnotetext{
${ }^{9}$ Dividends are usually tested over longer sample periods. However, we restrict our analyses to the years in which large numbers of annual reports are available on Dialog. This enables us to test the joint effect of disclosure and dividends on prices leading earnings.
} 
3503 firm-years observations. Of those, 1770 firm-years are high growth firms and 1733 firmyears are low growth firms.

Earnings per share data is calculated by dividing operating income before all exceptional items (Worldscope item 01250) by the outstanding number of shares. $X_{t}, X_{t+1}, X_{t+2}$ and $X_{t+3}$ are then defined as the earnings change for the periods $t, t+1, t+2$ and $t+3$ deflated by the share price. Both current and future earnings changes are deflated by the share price at the start of the return window for period $t . X_{t 3}$ is calculated as the aggregated future earnings over the following three years relative to the financial year end. We collect returns data from Datastream. $R_{t}, R_{t+1}$, $R_{t+2}$ and $R_{t+3}$ are measured as buy-and-hold returns starting from eight months before the financial year-end to four months after the financial year-end in year $t$. In the return measures, similar to Hussainey et al. (2003), we incorporate a four month lag to ensure that annual reports have been released. $R_{t 3}$ is calculated as the aggregated future returns over the following three years relative to the financial year end. Earnings yield, $E P_{t-1}$, is defined as period $t-1$ 's earnings over price four months after the financial year-end of period $t-1 . A G_{t}$ is the growth rate of total book value of assets for period $t$ (Datastream item 392).

We collect dividends per share from Worldscope (item 05101). ${ }^{10}$ The dividends dummy variable, Div, is set equal to one if firms pay dividends in year $t$ and zero otherwise. In addition to the above variables, we use a disclosure dummy variable to examine the effect of disclosure on the returns-earnings association. The disclosure dummy, $D$, is set equal to one for firms in the

10 Worldscope defines dividends per share (item 05101) as 'the total dividends per share declared during the calendar year for U.S. corporations and fiscal year for Non-U.S. corporations. It includes extra dividends declared during the year. Dividends per Share are based on the 'gross' dividend of a security, before normal withholding tax is deducted at a country's basic rate, but excluding the special tax credit available in some countries'. 
top two quartiles of the distributions of disclosure scores and zero otherwise. As mentioned earlier, we identify high (low) growth firms as those having below (above) median levels of BTMV. BTMV ratio is calculated as the inverse of the market to book value of equity ratio (Datastream item: MTBV).

Table 1 presents descriptive statistics for our regression variables. Panel A reports the descriptive analysis for the full sample. Panel B (C) reports the descriptive analysis for dividend (nondividend) paying firms. Panel D (E) reports the descriptive analysis for high- (low-) growth firms.

Table 1 shows that dividends were paid in $84 \%(=2952 / 3503)$ of the firm years in our sample. ${ }^{11}$ Panels $\mathrm{B}$ and $\mathrm{C}$ of Table 1 show that the median return in period $t$ is positive for dividend-paying firms, whilst it is negative for non-dividend-paying firms. The median current and future earnings change is positive for both dividend-paying and non-dividend-paying firms.

Panels B and C of Table 1 also show that dividend-paying firms, on average, have slightly higher mean and median levels of voluntary disclosure than non-dividend-paying firms. $56 \%$ of dividend-paying firms are in the category of high disclosure firms compared to $32 \%$ of nondividend-paying firms. ${ }^{12}$ The table shows a material difference in the disclosure scores between firms in high and low disclosure categories for both dividend and non-dividend-paying firms. The mean disclosure score ranges from 6.1 to 7.4 forward-looking earnings sentences for firms in the high disclosure category; whilst the mean disclosure score ranges from 1.4 to 1.8 forward-

\footnotetext{
${ }^{11}$ The proportion of dividend-paying firms for the overall population of UK firms is $69 \%$. This number is calculated by dividing the total number of dividend-paying firms on the total number of firms in the period of 1996-2002. This number is consistent with a recent study by Denis and Osobov (2008) which find that $73 \%$ of UK firms pay dividends in the sample period 1996 - 2002. However, in our sample, the proportion of dividend-paying firms is much higher than the overall population of dividend-paying firms. This is due to the deletion of inappropriate observations and observations with missing data in the sample period of 1996- 2002.

${ }^{12}$ The percentages are calculated as $56 \%=1655 / 2952$ and $32 \%=174 / 551$.
} 
looking earnings sentences for firms in the low disclosure category. The differences in means between high and low disclosure scores are statistically significant at the 1 per cent level (not reported in Table 1).

Panels D and $\mathrm{E}$ of Table 1 show that the median disclosure scores for the high and low disclosure groups is quite similar across high and low growth firms. The median disclosure score is 6 forward-looking earnings sentences for firms in the high disclosure category; whilst it is 2 forward-looking earnings sentences for firms in the low disclosure category. In addition, the differences in means between high and low disclosure scores are statistically significant at the 1 per cent level (not reported in Table 1). Panels D and E also show that the median return in period $t$ for high growth firms (3.3\%) is slightly lower than that for low growth firms $(4.3 \%)$. The median current and future earnings change is positive for both high and low growth firms. Finally, the median future earnings changes of low growth firms are higher than those of high growth firms.

\section{[Table 1 about here]}

\section{Main empirical results}

Our main empirical results are based on pooled regressions for the sample period 1996-2002. ${ }^{13}$ Table 2 reports these results. Column 2 reports the results for the full sample. Column 3 (4) reports the results for firms in the high (low) growth firms. Heteroscedasticity-consistent p-values are given in parentheses.

\footnotetext{
${ }^{13}$ Hanlon et al. (2007:16) argued that 'future earnings response regressions are likely to suffer from both crosssectional correlation (correlation across firms within a year) and time series correlation (over time within the same firm)'. We follow the method recommended by Petersen (2008) and used in Hanlon et al. (2007) by including year dummies to control for the time series correlation and by allowing for error clustering within firms (Rogers standard errors) to control for the cross-sectional correlation.
} 
[Table 2 about here]

\subsection{Disclosure and prices leading earnings}

Table 2, Column 2 presents the results of estimating equation (4) for the full sample. As expected, the coefficient associated with $X_{t}$ is positive and significant. The coefficient for $X_{t}$ is 0.80 with a p-value of 0.001 . However, the coefficient for $X_{t 3}$ is -0.06 with a p-value of 0.767 . This suggests that current stock price is positively associated with current earnings changes, but not with future earnings change. So there is no evidence that prices lead earnings for low disclosure firms that pay no dividends.

The incremental predictive value of high forward-looking earnings disclosures for anticipating future earnings is given by the coefficient on $D^{*} X_{t 3}$. The coefficient on $D^{*} X_{t 3}$ is 0.68 with a p-value of 0.031 . The significantly positive coefficient suggests that high disclosure firms that pay no dividends exhibit higher levels of share price anticipation of earnings three years ahead than low disclosure firms that pay no dividends. Thus the effect of disclosure on prices leading earnings is in line with the prior findings of Schliecher and Walker (1999); Lundholm and Myers (2002); Gelb and Zarowin (2002) and Hussainey et al. (2003). Based on these findings, we accept hypothesis 1 .

Table 2, Columns 3 and 4 reveal a number of significant differences between high and low growth firms. The current earnings variable exhibits a higher ERC for low growth firms than high growth firms. The coefficient on $X_{t}$ is 1.12 with a p-value of 0.001 for low growth firms, while it is positive (0.42), but insignificant, for high growth firms. The difference between the two coefficients is statistically significant at the 1 per cent level. 
We find no evidence of share price anticipation of earnings for high growth firms that pay no dividends and that provide low voluntary disclosures. For these firms, we obtain a statistically significant negative coefficient on $X_{t 3}$. This indicates that the market is unable to anticipate future earnings changes for high growth firms that provide low voluntary disclosure in their annual report discussion sections and that do not pay dividends in the current year. In contrast there is strong evidence that low growth low disclosure firms that do not pay dividends do exhibit share price anticipation of earnings for three years ahead. The coefficient on $X_{t 3}$ is positive and significant at the 1 per cent level.

Looking at the effect of disclosure on prices leading earnings, we find that the coefficient on $D^{*} X_{t 3}$ for high growth firms is 1.63 with a p-value of 0.036 . This coefficient indicates that narrative forward-looking earnings disclosures in high growth firms' annual reports improve the market's ability to anticipate future earnings change three years ahead. Based on this result we accept hypothesis 2 .

In contrast there appears to be no significant effect of disclosure on share price anticipation of earnings for low growth firms that do not pay dividends. The coefficient on $D^{*} X_{t 3}$, for high disclosure low growth firms is 0.19 with a p-value of 0.467 . Thus, the voluntary disclosures of low growth firm do not appear to improve the stock market's ability to anticipate future earnings changes. This leads us to reject hypothesis 3.

Overall our evidence for low growth firms suggests that the market is able to forecast future earnings changes, but this ability is neither linked to nor improved by forward-looking earnings statements in annual report narrative sections. The evidence for high growth firms supports the view that the market has particular difficulties in forecasting firms' future earnings changes, 
however that this difficulty is partially overcome by increasing the number of forward-looking earnings information in annual report narrative sections.

We also test for differences between high growth firms and low growth firms. We test the extent to which the association between share price anticipation of earnings and disclosure is significantly stronger for high growth firms than for low growth firms. We perform this test by including all high and low growth firms in one dataset. Then, before running our analyses, we create a dummy variable to be equal 1 for high growth firms and zero otherwise. Finally, we interact the high growth dummy variable throughout the model. We find a positive and significant coefficient on Growth $* D^{*} X_{t 3}$ of 0.50 with a p-value of 0.020 (not reported in Table 2). This suggests that that the strength of the degree of association between share price anticipation of earnings and voluntary disclosure is stronger for high growth firms than for low growth firms. This leads us to accept hypothesis 4 .

\subsection{Dividends and prices leading earnings}

As discussed earlier, voluntary disclosure is one of the ways that firms provide information about future earnings to the market. Another way that firms can provide information is through dividend policy. Here we examine the extent to which dividend propensity improves the stock market's ability to anticipate future earnings changes. The incremental predictive effect of dividend propensity on share price anticipation of earnings is given by the coefficient on $\operatorname{Div}^{*} X_{t 3}$.

Column 2 Table 2 shows that the coefficient on $\operatorname{Div}^{*} X_{t 3}$ is positive and significant. This coefficient is 0.51 with a $\mathrm{p}$-value of 0.025 . This indicates that paying dividends improves the 
market's ability to anticipate future earning changes. The significant positive coefficient indicates that low disclosure firms that pay dividends exhibit higher levels of share price anticipation of earnings than low disclosure firms that pay no dividends. The significant effect of dividend propensity on prices leading earnings is in line with the findings of Hanlon et al. (2007). Based on these findings, we accept hypothesis 5 .

Table 2 Column 3 shows that the coefficient on $D i v * X_{t 3}$ for high growth firms is 1.62 with a pvalue of 0.001 . This coefficient demonstrates that high growth dividend-paying firms exhibit significantly higher levels of share price anticipation of earnings than high growth non-dividendpaying firms. Based on this result we accept hypothesis 6 .

In contrast, Table 2 Column 4 shows that the coefficient on $D i v * X_{t 3}$ for low growth firms is negative and insignificant. Thus, there is no evidence that the dividend propensity of low growth firms is associated with an improvement in the market's ability to anticipate future earnings changes. Based on this result we reject hypothesis 7.

Overall our evidence indicates that there is a material difference between high and low growth firms in the association between dividend propensity and share price anticipation of earnings. For high growth firms we find that the ability of the market to anticipate future earnings changes is significantly greater when the firm pays dividends in the current year. We find no such evidence for low growth firms.

We test for a difference between high growth and low growth firms by interacting a dummy variable for high growth throughout the model. We find a positive and significant coefficient on Growth $* \operatorname{Div}^{*} X_{t 3}$ of 1.41 with a p-value of 0.001 (not reported in Table 2). This suggests that 
the strength of the degree of association between share price anticipation of earnings and dividend propensity is stronger for high growth firms than for low growth firms. This leads us to accept hypothesis 8 .

Summarising the results for the above hypotheses (H1-H8), we find that both dividend propensity and high disclosure are positively associated with share price anticipation of earnings for high growth firms. However, there is no evidence of similar effects for low growth firms.

\subsection{The Joint effect of disclosure and dividends on prices leading earnings}

We now turn to the hypotheses which are concerned with the joint effects of high disclosure and dividend propensity on prices leading earnings. The incremental predictive value of both high disclosure and dividend propensity for anticipating future earnings is given by the coefficient on $D^{*} \operatorname{Div}^{*} X_{t 3}$. Column 2, Table 2 shows some evidence of a substitution effect. The coefficient on the interaction variable $D * D i v * X_{t 3}$ is negative $(-0.44)$ and statistically insignificant at an accepted level. This indicates that both disclosure and dividends provide related information, but some of the information is common to both i.e. the effects are 'partially additive'. Our best estimate for the combined effect of disclosure and dividend is 0.75 (i.e. $0.68+0.51-0.44$ ] which is smaller than the sum of the coefficients on $D^{*} X_{t 3}$ and $D i v * X_{t 3}[1.19=0.68+0.51]$ with a p-value of 0.001 (not reported in Table 2). However, because of the insignificant coefficient on $D^{*} \mathrm{Div}^{*} X_{t 3}$, it is not safe to assume that the combined effect of disclosure and dividends is additive. Therefore, we reject hypothesis 9 .

For high growth firms, we also find some evidence of a substitution effect. The coefficient on the interaction variable $D^{*} D i v^{*} X_{t 3}$ is negative $(-1.68)$ and significantly significant at the 10 per 
cent level. This indicates that disclosure and dividends provide related information, but some of the information is common to both. Thus, it is not safe to assume that the combined effect of high disclosure and dividend propensity is perfectly additive. Our best estimate is that the combined effect of dividend propensity and high disclosure is 1.57 (i.e. $1.63+1.62-1.68$ ) with a p-value of 0.001 (not reported in Table 2), which is below the first order effect for high disclosure and below the first order effect of dividend propensity. In this case, the inference is that both dividend propensity and voluntary disclosure are strict substitutes for high growth firms. Based on these findings we reject hypothesis 10 .

As the results for the low growth firms indicate that there is no first order effects either for dividend propensity or voluntary disclosure, we find that the coefficient on $D^{*} D i v^{*} X_{t 3}$ is positive (close to zero) and statistically insignificant at an accepted level. Based on these findings we reject hypothesis 11.

Finally, we test for differences between high growth and low growth firms by including an additional dummy variable for high growth firms. We test the extent to which the association between the joint effect of voluntary disclosure and the payments of dividends on prices leading earnings are significantly stronger for high growth firms than for low growth firms. The analysis shows a negative significant coefficient on Growth $D^{*} D i v * X_{t 3}$ of -1.83 with a p-value of 0.067 (not reported in Table 2). This significantly negative coefficient indicates that dividend propensity and high voluntary disclosure are strict substitutes for high growth firms. We do not find such evidence for low growth firms. This leads us to reject hypothesis 12 . 


\section{Robustness analysis}

In this section we examine the sensitivity of our results to the determinants of the earnings response coefficients. Lundholm and Myers (2002) examine a number of determinants of current earnings response coefficient when exploring the association between share price anticipation of earnings and corporate disclosure. These determinants include loss status, growth, beta, earnings persistence, size and the sign of the current return. Hanlon et al. (2007) examine a similar set of determinants when exploring the association between share price anticipation of earnings and dividend propensity. The results of both studies (after the inclusion of control variables) remain consistent with the original findings indicating that these control variables do not drive the association between disclosure (and dividends) and share price anticipation of earnings.

Schleicher et al. (2007) provide evidence that the association between annual report narratives and share price anticipation of earnings is not the same for profitable and unprofitable firms. They find that the ability of stock returns to anticipate the next year's earnings change is significantly stronger for high disclosure unprofitable. They do not find the same result for profitable firms. Therefore, based on the results in Schleicher et al. (2007), we examine the sensitivity of our results to firm profitability status. Similar to Schleicher et al. (2007) we define a loss (profit) as negative (positive) operating income before all (operating and non-operating) exceptional items (Worldscope item 01250).

To examine the effect of losses on the association between disclosure, dividends and prices leading earnings, we divide our sample into two categories; unprofitable firms and profitable firms. Then, we run our regression model (equation 4) for each category. The results are reported in Table 3. 
[Table 3 about here]

Consistent with Schleicher et al. (2007), Columns 2.1 and 3.1 of Table 3 show that high disclosure increases the market's ability to anticipate future earnings changes for unprofitable firms - but not for profitable firms. The coefficient on $D^{*} X_{t 3}$ is positive (1.01) and statistically significant at the 5 per cent level for unprofitable firms, whilst it is smaller and insignificant for profitable firms.

Table 3 shows that several of our previous findings still hold after separating our sample into unprofitable firms and profitable firms. In particular, Column 3.3 shows that the market is able to anticipate future earnings changes for low growth profitable firms (the coefficient on $X_{t 3}$ is significantly positive at the 5 per cent level). This ability is neither linked to nor improved by high disclosure or dividend propensity. In addition, Columns 2.2 and 3.2 show that the market has particular difficulties in anticipating future earnings changes for high growth profitable and unprofitable firms. The coefficient on $X_{t 3}$ for these firms is negative.

Consistent with results in Table 2, we find that the effect of high disclosure on prices leading earnings is positive for high growth firms regardless of their profitability status. The coefficient on $D X_{t 3}$ is 0.93 with a $\mathrm{p}$ value of 0.209 for high growth unprofitable firms and 1.47 with a $\mathrm{p}$ value of 0.160 for high growth profitable firms. Table 3 also shows that the effect of disclosure on prices leading earnings for high growth firms is greater than the effect for low growth firms regardless of the profitability of the firms. In particular, the coefficient on $D X_{t 3}$ is higher for high growth unprofitable firms than for low growth unprofitable firms. However, the difference between high growth unprofitable firms and low growth unprofitable firms is not statistically 
significant (not reported in Table 3). ${ }^{14}$ On the other hand, the effect of disclosure on prices leading earnings for high growth profitable firms is significantly greater than the effect for low growth profitable firms (significant at the 10 per cent level; not reported in Table 3). The results suggest that the strength of the degree of association between share price anticipation of earnings and voluntary disclosure is greater for high growth firms than for low growth firms.

Consistent with results in Table 2, we find that the effect of dividend propensity on prices leading earnings is positive for high growth firms, while it is negative or close to zero for low growth firms. However, the effect for high growth firms is only statistically significant for high growth profitable firms at the 1 per cent level.

The effect of dividend propensity on prices leading earnings is significantly greater for high growth firms than for low growth firms, in both profitability subsamples. For unprofitable firms the coefficient on $\mathrm{Div}^{*} X_{t 3}$ is 1.08 with a p-value of 0.390 for high growth unprofitable firms, while it is 0.08 with a p-value of 0.883 for low growth unprofitable firms. The difference between high and low growth unprofitable firms is statistically significant at the 10 per cent level (not reported in Table 3). For profitable firms the coefficient on $\operatorname{Div}^{*} X_{t 3}$ is 1.51 and significant at the 1 per cent level for high growth firms, while it is negative and insignificant for low growth firms. The difference between high and low growth profitable firms is statistically significant at the 1 per cent level (not reported in Table 3). These results confirm that the strength of the degree of association between share price anticipation of earnings and dividend propensity is greater for high growth firms than for low growth firms.

\footnotetext{
${ }^{14}$ As mentioned earlier, we statistically test the actual differences between high growth and low growth firms by interacting a dummy variable for high growth throughout Equation (4).
} 
A particularly interesting feature of Table 3 is the way that the joint effect of dividend propensity and disclosure varies between profitable and unprofitable firms. In particular the results suggest some (weak) evidence of a complementary effect for high growth unprofitable firms. The subsitution effect that we reported in Table 2 is confirmed in the high growth profitable subsample, although it is no longer statistically significant. The difference between high growth unprofitable and high growth profitable firms for the coefficient on $D^{*} \mathrm{Div}^{*} X_{t 3}$ is significant at the 1 per cent level (not reported in Table 3 ).

Finally it is worth noting that for high growth unprofitable firms the combined effects of high disclosure and dividend propensity are very considerable $(0.93+1.08+1.68=3.69)$. High growth

unprofitable firms are the firms for which current earnings is least relevant (revealed by a negative current ERC), and for which the combined effects of narrative disclosure and dividend propensity are the most useful for predicting future earnings.

\section{Conclusion}

This paper builds on literature that examines the link between narrative disclosures and prices leading earnings.

We extend this work in two important ways. First, it is well known that financial policy choices, such as dividend signalling, potentially offer an alternative set of devices for conveying value relevant information to the market. In particular firms that pay dividends may use changes in dividends to signal future profitability. We investigate whether firms that pay dividends exhibit higher levels of share price anticipation of earnings, and whether dividend propensity acts as a substitute for narrative disclosure in financial communication. 
Second we investigate whether firm growth characteristics affect the extent to which prices lead earnings, and whether the importance of dividend signalling and narrative disclosures varies between high and low growth firms.

Our results show a number of significant differences between high and low growth firms. We find that high growth, low disclosure firms that pay no dividends exhibit no share price anticipation of earnings. On the other hand, we find that low growth, low disclosure firms that pay no dividends exhibit significant share price anticipation of earnings. We also find that dividend propensity and high voluntary disclosure improve the market's ability to anticipate future earnings changes for high growth firms, but not for low growth firms.

With regard to the additvity or otherwise of disclosure and dividend propensity we find, for the high growth firm subsample for which both of the individual effects are significant, that the effects of voluntary disclosure and dividend propensity on the degree of share price anticipation of earnings are not perfectly additive.

This paper is the first to study effect of firm specific growth characteristics on the association between voluntary disclosures, dividend propensity and prices leading earnings. Whilst we focus only on the growth characteristics of firms it would also be interesting to examine the effect of other firms characteristics such as risk.

Another interesting issue for future work would be to consider the factors that determine the choice between dividend signalling and increased disclosure as alternative forms of financial communication for high growth firms. For example, is it the case that firms with potentially high third party disclosure costs are more likely to use dividend signalling? 
Finally it is worth noting that the dividend propensity of UK firms has recently declined (Vieira and Raposo, 2007), although this has to some extent been offset by an increase in share repurchases. Future work could test for a change in the dividend propensity effect following an overall decline in dividend propensity, and it could also test to see if share repurchases are associated with greater share price anticipation of earnings. 


\section{References}

Abdolmohammadi, M., Simnett, R., Thibodeau, J. and Wright, A. (2006). 'Sell-side analysts' reports and the current external reporting model'. Accounting Horizons, 20(4): 375-389.

Allen, F. and Michaely.R. (2003). 'Payout policy'. In: Constantinides, G. , Milton, H., and Réne S., editors, Handbook of Economics. North Holland, Amsterdam, 337-430.

Amir, E. and Lev, B. (1996). 'Value relevance of non-financial information: the wireless communications industry'. Journal of Accounting and Economics, 22(1-3): 3-30.

Banghøj, J. and Plenborg, T. (2008). 'Value relevance of voluntary disclosure in the annual report', Accounting and Finance, 48: 159-180.

Bank, S.A., Cheffins, B.R. and Goergen, M. (2006). 'Dividends and politics', Working paper no. 24/2004, ECGI Working Paper Series in Law, The European Corporate Governance Institute.

Benartzi, S., Michaely, R. and Thaler, R. (1997). 'Do changes in dividends signal the future or the past?'. Journal of Finance, 52(3): 1007-1034.

Brown, S., Lo, K. and Lys, T. (1999). 'Use of $\mathrm{R}^{2}$ in accounting research: measuring changes in value relevance over the last four decades'. Journal of Accounting and Economics, 28(2): 83-115.

Collins, D.W. and Kothari, S.P. (1989). 'An analysis of intertemporal and cross sectional determinants of earnings response coefficients'. Journal of Accounting and Economics, 11 (2-3): 143-181.

Collins, D.W., Kothari, S.P., Shanken, J. and Sloan, R.G. (1994). 'Lack of timeliness and noise as explanations for the low contemporaneous return-earnings association'. Journal of Accounting and Economics, 18(3): 289-324.

Denis, D. and Osobov, I. (2008). 'Why do firms pay dividends? international evidence on the determinants of dividend policy'. Journal of Financial Economics, 89: 62-82.

Dhiensiri, N., Sayrak, A. and Zarowin, P. (2005). 'The impact of analyst coverage initiation on the market's ability to anticipate future earnings'. Working paper, Massey University.

Eades, K. M. (1982). 'Empirical evidence on dividends as a signal of firm value'. Journal of Financial and Quantitative Analysis, 17(4): 471-500.

Ertimur, Y. (2004). 'Accounting numbers and information asymmetry: Evidence from loss firms'. Working paper, Stanford University.

Ettredge, M.L., Kwon, S.Y., Smith, D.B. and Zarowin, P.A. (2005). 'The impact of SFAS No. 131 business segment data on the market's ability to anticipate future earnings'. Accounting Review, 80(3): 773-804. 
Francis, J. and Schipper, K. (1999). 'Have financial statements lost their relevance?'. Journal of Accounting Research, 37(2): 319-352.

Garcia-Borbolla, A., Larran-Jorge, M. and Rees, W. (2004), 'The value relevance of earnings and dividends in Europe', Working paper, University of Cadiz.

Gelb, D.S. (2002). 'Intangible assets and firms' disclosures: an empirical investigation'. Journal of Business Finance and Accounting, 29(3 \& 4): 457-476.

Gelb, D.S. and Zarowin, P. (2002). 'Corporate disclosure policy and the informativeness of stock prices'. Review of Accounting Studies, 7: 33-52.

Grullon, G., Michaely, R., Benartizi., S. and Thaler, R. (2003). 'Dividend changes do not signal changes in future profitability'. Journal of Business, 78(5): 1659-1682.

Grullon, G., Michaely, R. and Swaminathan, B. (2002). 'Are dividend changes a sign of firm maturity?'. Journal of Business, 75(3): 387-424.

Hanlon M., Myers, J., and Shevlin, T. (2007). 'Are dividends informative about future earnings?' Working paper, University of Michigan.

Hussainey, K., Schleicher, T. and Walker, M. (2003). 'Undertaking large-scale disclosure studies when AIMR-FAF ratings are not available: the case of prices leading earnings'. Accounting and Business Research, 33(4): 275-294.

Hyyitinen, A. and Pajarinen, M. (2005). 'External finance, firm growth and the benefits of information disclosure: evidence from Finland'. European Journal of Law and Economics, 19: 69-93.

Jensen, M. (1986). 'Agency costs of free cash flow, corporate finance and takeovers'. American Economic Review, 76, 323-329.

Khurana, I., Pereira, R. and Martin, X. (2006). 'Firm growth and disclosure: an empirical analysis'. Journal of Financial and Quantitative Analysis, Forthcoming.

Kothari, S.P., Laguerre, T.E and Leone, A.J. (2002). 'Capitalization versus expensing: evidence on the uncertainty of future earnings from capital expenditure versus R\&D outlays'. Review of Accounting Studies, 7: 355-382.

Kwon, S. (2002). 'Financial analysts' forecasts accuracy and dispersion: high-tech versus lowtech stocks'. Review of Quantitative Finance and Accounting, 19(1): 65-91.

Lee, B. B., Cox, S. and Roden, D. (2007). 'Have the big accounting firms lost their audit quality advantage: evidence from the returns-earnings relation'. Journal of Forensic Accounting, VIII: 271-286. 
Lee, B.B., Press, E. and Choi, B.B. (2005). 'Why is the value relevance of earnings lower for high-tech firms?' Working paper, Prairie View A\&M University.

Lev, B. (1989). 'On the usefulness of earnings: lessons and directions from two decades of empirical research'. Journal of Accounting Research, 27(Supplement): 153-92.

Lev, B. (2001). Intangibles: Management, Measurement and Reporting, The Brookings Institution Press.

Lev, B. and Sougiannis, T. (1996). 'The capitalization, amortization and value-relevance of R\&D'. Journal of Accounting and Economics, 21(1): 107-138.

Lev, B. and Zarowin, P. (1999). 'The boundaries of financial reporting and how to extend them'. Journal of Accounting Research, 37(2): 353-385.

Lundholm, R.J. and Myers, L.A. (2002). 'Bringing the future forward: the effect of disclosure on the returns-earnings relation'. Journal of Accounting Research, 40(3): 809-39.

Morgan, G. and Thomas, S. (1998). 'Taxes, dividend yields and returns in the UK equity market'. Journal of Banking \& Finance, 22, 405-423.

Nam, J., Thornton Jr. J., Viswanath, P. and Wang, J. (2008). 'Information revelation through dividend initiations', Working paper, Kent State University.

Orpurt, S. and Zang, Y. (2006). 'Do direct cash flow disclosures improve the market's ability to anticipate future cash flows and earnings?'. Working paper, Singapore Management University.

Oswald, D. and Young, S. (2008). 'Tax-efficient irregular payout methods: the case of B share schemes and capital repayments via a court-approved scheme of arrangement'. Accounting and Business Research. 38(1): 49-70.

Oswald, D. R. and Zarowin, P. (2007). 'Capitalization of R\&D and the informativeness of stock prices'. European Accounting Review, 16(4): 703-726.

Petersen, M.A. (2008). 'Estimating standard errors in finance panel data sets: comparing approaches'. Review of Financial Studies, Forthcoming.

Rayburn, J. (1986). 'The association of operating cash flow and accruals with security returns'. Journal of Accounting Research, 24(Supplement): 112-137.

Schleicher, T., Hussainey, K. and Walker, M. (2007). 'Loss firms' annual report narratives and share price anticipation of earnings'. The British Accounting Review, 39(2), 153-171.

Schleicher, T. and Walker, M. (1999). 'Share price anticipation of earnings and management's discussion of operations and financing'. Accounting and Business Research, 29(4): 321-335. 
Skinner, D. (2004) 'What do dividends tell us about earnings quality.' Working paper. University of Chicago.

Skinner, D., (2008) 'The evolving relation between earnings, dividends, and stock repurchases'. Journal of Financial Economics, 87: 582-609.

Thornhill, S. and Gellatly, G. (2005), 'Intangible assets and entrepreneurial finance: the role of growth history and growth expectations'. The International Entrepreneurship and Management Journal, 1(2): 135-148.

Tucker, J.W. and Zarowin, P.A. (2006). 'Does income smoothing improve earnings informativeness?'. Accounting Review, 81(1): 251-270.

Vieira, E.S. and Raposo, C.C. (2007). 'Lower propensity to pay dividends? new evidence from europe'. Working paper. Universidade de Aveiro.

Walker, M. (2004). 'Market based accounting research', in C. Clubb ed. Blackwells Encyclopaedia of Management, Volume 1. Blackwell's. 
Table 1. Descriptive statistics.

\begin{tabular}{|c|c|c|c|}
\hline Variable & Mean & Median & OBS \\
\hline \multicolumn{4}{|c|}{ Panel A: Full sample } \\
\hline$R_{t}$ & 0.089 & 0.038 & 3503 \\
\hline$X_{t}$ & 0.007 & 0.008 & 3503 \\
\hline$X_{t 3}$ & 0.006 & 0.005 & 3503 \\
\hline$R_{t 3}$ & 0.295 & 0.222 & 3503 \\
\hline$A G_{t}$ & 0.173 & 0.078 & 3503 \\
\hline$E P_{t-1}$ & 0.091 & 0.093 & 3503 \\
\hline Disclosure $=$ Low & 1.7 & 2 & 1674 \\
\hline Disclosure $=$ High & 7.2 & 6 & 1829 \\
\hline \multicolumn{4}{|c|}{ Panel B: Dividend-paying firms } \\
\hline$R_{t}$ & 0.116 & 0.065 & 2952 \\
\hline$X_{t}$ & 0.006 & 0.008 & 2952 \\
\hline$X_{t 3}$ & -0.002 & 0.003 & 2952 \\
\hline$R_{t 3}$ & 0.301 & 0.237 & 2952 \\
\hline$A G_{t}$ & 0.171 & 0.085 & 2952 \\
\hline$E P_{t-1}$ & 0.119 & 0.102 & 2952 \\
\hline Disclosure $=$ Low & 1.8 & 2 & 1297 \\
\hline Disclosure $=$ High & 7.4 & 6 & 1655 \\
\hline \multicolumn{4}{|c|}{ Panel C: Non-dividend-paying firms } \\
\hline$R_{t}$ & -0.055 & -0.187 & 551 \\
\hline$X_{t}$ & 0.017 & 0.001 & 551 \\
\hline$X_{t 3}$ & 0.050 & 0.024 & 551 \\
\hline$R_{t 3}$ & 0.267 & 0.082 & 551 \\
\hline$A G_{t}$ & 0.184 & 0.015 & 551 \\
\hline$E P_{t-1}$ & -0.058 & -0.020 & 551 \\
\hline Disclosure $=$ Low & 1.4 & 1 & 377 \\
\hline Disclosure $=$ High & 6.1 & 5 & 174 \\
\hline \multicolumn{4}{|c|}{ Panel D: High growth firms } \\
\hline$R_{t}$ & 0.089 & 0.033 & 1770 \\
\hline$X_{t}$ & 0.007 & 0.008 & 1770 \\
\hline$X_{t 3}$ & 0.002 & 0.003 & 1770 \\
\hline$R_{t 3}$ & 0.234 & 0.166 & 1770 \\
\hline$A G_{t}$ & 0.220 & 0.114 & 1770 \\
\hline$E P_{t-1}$ & 0.073 & 0.079 & 1770 \\
\hline
\end{tabular}




\begin{tabular}{|l|c|c|c|}
\hline Disclosure = Low & 1.7 & 2 & 828 \\
\hline Disclosure = High & 7.3 & 6 & 942 \\
\hline Panel E: Low growth firms & 0.089 & 0.043 & 1733 \\
\hline$R_{t}$ & 0.008 & 0.007 & 1733 \\
\hline$X_{t}$ & 0.010 & 0.007 & 1733 \\
\hline$X_{t 3}$ & 0.358 & 0.284 & 1733 \\
\hline$R_{t 3}$ & 0.124 & 0.050 & 1733 \\
\hline$A G_{t}$ & 0.110 & 0.116 & 1733 \\
\hline$E P_{t-1}$ & 1.7 & 2 & 846 \\
\hline Disclosure = Low & 7.1 & 6 & 887 \\
\hline Disclosure = High &
\end{tabular}

Table 1 presents descriptive statistics. Panel A reports the descriptive analysis for the full sample. Panel B (C) reports the descriptive analysis for dividend (non-dividend) paying firms. Panel D (E) reports the descriptive analysis for high (low) growth firms. Returns, $R_{t}$, is calculated as buyand-hold returns from eight months before the financial year-end to four months after the financial year-end. $R_{t 3}$ is the aggregated three years future returns. The earnings variable, $X_{t}$, is defined as earnings change per share deflated by the share price four months after the end of the financial year $t-1 . X_{t 3}$ is the aggregated three years future earnings change Earnings measure is the Worldscope item 01250 which is operating income before all exceptional items. $E P_{t-1}$ is defined as period $t-1$ 's earnings over price four months after the financial year-end of period $t-1$. $A G_{t}$ is the growth rate of total book value of assets for period $t$ (Datastream item 392). Firm-years with a disclosure score on top (bottom) $50 \%$ of the distribution of disclosure scores are defined as high (low) disclosure firm-year. Dividend (non-dividend) paying firms are those pay (not pay) dividends at the current year. Dividends measure is dividends per share (Worldscope item 05101). High growth firms are defined as those having below median levels of BTMV, while low growth firms are defined as those having above median levels of BTMV. BTMV ratio is calculated as the inverse of the market to book value of equity ratio (Datastream item MTBV). 
Table 2. Regression results: The effect of disclosure and dividend propensity on prices leading earnings.

\begin{tabular}{|c|c|c|c|}
\hline Independent variable & $\begin{array}{c}\text { Full sample } \\
\text { (2) }\end{array}$ & $\begin{array}{c}\text { High growth firms } \\
\text { (3) }\end{array}$ & $\begin{array}{c}\text { Low growth firms } \\
\text { (4) }\end{array}$ \\
\hline Intercept & $\begin{array}{c}0.01 \\
(0.710)\end{array}$ & $\begin{array}{c}0.04 \\
(0.405)\end{array}$ & $\begin{array}{c}-0.03 \\
(0.464)\end{array}$ \\
\hline$X_{t}$ & $\begin{array}{l}0.80 * * * \\
(0.001)\end{array}$ & $\begin{array}{c}0.42 \\
(0.356)\end{array}$ & $\begin{array}{l}1.12 * * * \\
(0.001)\end{array}$ \\
\hline$X_{t 3}$ & $\begin{array}{l}-0.06 \\
(0.767)\end{array}$ & $\begin{array}{c}-0.63 * * \\
(0.031)\end{array}$ & $\begin{array}{l}0.44 * * * \\
(0.005)\end{array}$ \\
\hline$R_{t 3}$ & $\begin{array}{l}-0.10 * * * \\
(0.001)\end{array}$ & $\begin{array}{c}-0.12 * * * \\
(0.001)\end{array}$ & $\begin{array}{c}-0.12 * * * \\
(0.001)\end{array}$ \\
\hline$A G_{t}$ & $\begin{array}{c}0.07 \\
(0.158) \\
\end{array}$ & $\begin{array}{c}0.06 \\
(0.325) \\
\end{array}$ & $\begin{array}{c}0.09 \\
(0.353) \\
\end{array}$ \\
\hline$E P_{t-1}$ & $\begin{array}{l}0.49 * * * \\
(0.009)\end{array}$ & $\begin{array}{c}0.12 \\
(0.737) \\
\end{array}$ & $\begin{array}{l}0.83 * * * \\
(0.001)\end{array}$ \\
\hline$D$ & $\begin{array}{l}-0.09^{*} \\
(0.086) \\
\end{array}$ & $\begin{array}{c}-0.18 * * \\
(0.011) \\
\end{array}$ & $\begin{array}{l}-0.01 \\
(0.874) \\
\end{array}$ \\
\hline$D^{*} X_{t}$ & $\begin{array}{c}0.62^{*} \\
(0.066)\end{array}$ & $\begin{array}{l}1.78 * * * \\
(0.005)\end{array}$ & $\begin{array}{c}0.21 \\
(0.623)\end{array}$ \\
\hline$D * X_{t 3}$ & $\begin{array}{l}0.68 * * \\
(0.031)\end{array}$ & $\begin{array}{l}1.63 * * \\
(0.036)\end{array}$ & $\begin{array}{c}0.19 \\
(0.467)\end{array}$ \\
\hline$D * R_{t 3}$ & $\begin{array}{c}0.06 \\
(0.175) \\
\end{array}$ & $\begin{array}{c}0.10 \\
(0.116) \\
\end{array}$ & $\begin{array}{c}0.04 \\
(0.494) \\
\end{array}$ \\
\hline$D * A G_{t}$ & $\begin{array}{c}0.06 \\
(0.483)\end{array}$ & $\begin{array}{c}0.11 \\
(0.382)\end{array}$ & $\begin{array}{c}0.05 \\
(0.722)\end{array}$ \\
\hline$D * E P_{t-1}$ & $\begin{array}{c}0.19 \\
(0.488)\end{array}$ & $\begin{array}{c}0.69 \\
(0.166)\end{array}$ & $\begin{array}{c}0.16 \\
(0.508)\end{array}$ \\
\hline Div & $\begin{array}{c}0.05 \\
(0.241)\end{array}$ & $\begin{array}{c}0.07 \\
(0.259)\end{array}$ & $\begin{array}{c}0.06 \\
(0.203)\end{array}$ \\
\hline $\operatorname{Div} * X_{t}$ & $\begin{array}{l}0.92 * * * \\
(0.009) \\
\end{array}$ & $\begin{array}{l}2.01 * * \\
(0.012) \\
\end{array}$ & $\begin{array}{c}0.48 \\
(0.194) \\
\end{array}$ \\
\hline $\operatorname{Div}^{*} X_{t 3}$ & $\begin{array}{l}0.51 * * \\
(0.025) \\
\end{array}$ & $\begin{array}{l}1.62 * * * \\
(0.001)\end{array}$ & $\begin{array}{c}-0.13 \\
(0.502) \\
\end{array}$ \\
\hline$D i v * R_{t 3}$ & $\begin{array}{c}0.06^{*} \\
(0.066)\end{array}$ & $\begin{array}{c}0.07 \\
(0.171)\end{array}$ & $\begin{array}{c}0.09 * \\
(0.058)\end{array}$ \\
\hline$D i v * A G_{t}$ & $\begin{array}{c}0.07 \\
(0.296) \\
\end{array}$ & $\begin{array}{c}0.06 \\
(0.455) \\
\end{array}$ & $\begin{array}{c}0.06 \\
(0.562) \\
\end{array}$ \\
\hline$D i v * E P_{t-1}$ & $\begin{array}{c}0.21 \\
(0.389)\end{array}$ & $\begin{array}{c}0.34 \\
(0.480)\end{array}$ & $\begin{array}{l}-0.04 \\
(0.886)\end{array}$ \\
\hline$D * D i v$ & $\begin{array}{c}0.10 \\
(0.127) \\
\end{array}$ & $\begin{array}{c}0.13 \\
(0.136) \\
\end{array}$ & $\begin{array}{c}0.04 \\
(0.674) \\
\end{array}$ \\
\hline$D * D i v * X_{t}$ & $\begin{array}{l}-0.50 \\
(0.290)\end{array}$ & $\begin{array}{l}-2.19 * * \\
(0.039)\end{array}$ & $\begin{array}{l}-0.03 \\
(0.961)\end{array}$ \\
\hline$D * D_{i v}^{*} X_{t 3}$ & $\begin{array}{l}-0.44 \\
(0.220)\end{array}$ & $\begin{array}{l}-1.68 * \\
(0.064) \\
\end{array}$ & $\begin{array}{c}0.07 \\
(0.845) \\
\end{array}$ \\
\hline$D * D_{i v}^{*} R_{t 3}$ & $\begin{array}{l}-0.05 \\
(0.357)\end{array}$ & $\begin{array}{l}-0.08 \\
(0.293)\end{array}$ & $\begin{array}{l}-0.03 \\
(0.664)\end{array}$ \\
\hline$D * D i v * A G_{t}$ & $\begin{array}{l}-0.11 \\
(0.288) \\
\end{array}$ & $\begin{array}{l}-0.10 \\
(0.461) \\
\end{array}$ & $\begin{array}{l}-0.13 \\
(0.397) \\
\end{array}$ \\
\hline$D * D i v * E P_{t-1}$ & $\begin{array}{c}-0.48 \\
(0.158) \\
\end{array}$ & $\begin{array}{c}-0.66 \\
(0.316) \\
\end{array}$ & $\begin{array}{l}-0.56^{*} \\
(0.098)\end{array}$ \\
\hline Observations & 3503 & 1770 & 1733 \\
\hline $\mathrm{R}^{2}$ & 0.157 & 0.176 & 0.183 \\
\hline
\end{tabular}


and-hold returns from eight months before the financial year-end to four months after the financial year-end. $R_{t 3}$ is the aggregated three years future returns. The earnings variable, $X_{t}$, is defined as earnings change per share deflated by the share price four months after the end of the financial year $t-1 . X_{t 3}$ is the aggregated three years future earnings change Earnings measure is the Worldscope item 01250 which is operating income before all exceptional items. $E P_{t-1}$ is defined as period $t-1$ 's earnings over price four months after the financial year-end of period $t-1$. $A G_{t}$ is the growth rate of total book value of assets for period $t$ (Datastream item 392). Firms with a disclosure score in the top (bottom) $50 \%$ of the distribution of disclosure scores are defined as high (low) disclosure firms. The dummy variable, $D$, is set equal to 1 ( 0 ) for high (low) disclosure firms. Dividends measure is dividends per share (Worldscope item 05101). The dummy variable, Div, is set equal to 1 (0) for firms that pay (not pay) dividends at the current year. High growth firms are defined as those having below median levels of BTMV, while low growth firms are defined as those having above median levels of BTMV. BTMV ratio is calculated as the inverse of the market to book value of equity ratio (Datastream item $M T B V$ ). The significance levels (two-tail test) are: $*=10$ per cent, $* *=5$ per cent, $* * *=1$ per cent. 
Table 3. Robustness analysis: comparing unprofitable with profitable firms

\begin{tabular}{|c|c|c|c|c|c|c|}
\hline \multirow{2}{*}{$\begin{array}{l}\text { Independent } \\
\text { variable } \\
\text { (1) }\end{array}$} & \multicolumn{3}{|c|}{ Unprofitable firms (2) } & \multicolumn{3}{|c|}{$\begin{array}{l}\text { Profitable firms (3) } \\
\end{array}$} \\
\hline & $\begin{array}{c}\text { Full sample } \\
(2.1)\end{array}$ & $\begin{array}{l}\text { High growth } \\
\text { firms }(2.2)\end{array}$ & $\begin{array}{l}\text { Low growth } \\
\text { firms }(2.3)\end{array}$ & $\begin{array}{c}\text { Full sample } \\
(3.1)\end{array}$ & $\begin{array}{l}\text { High growth } \\
\text { firms (3.2) }\end{array}$ & $\begin{array}{l}\text { Low growth } \\
\text { firms (3.3) }\end{array}$ \\
\hline Intercept & $\begin{array}{c}-0.14 * \\
(0.087) \\
\end{array}$ & $\begin{array}{c}-0.01 \\
(0.957) \\
\end{array}$ & $\begin{array}{c}-0.26 * * * \\
(0.001)\end{array}$ & $\begin{array}{c}0.08 \\
(0.285)\end{array}$ & $\begin{array}{c}0.06 \\
(0.556) \\
\end{array}$ & $\begin{array}{c}0.05 \\
(0.617)\end{array}$ \\
\hline$X_{t}$ & $\begin{array}{c}-0.28 \\
(0.343) \\
\end{array}$ & $\begin{array}{c}-0.90 \\
(0.122) \\
\end{array}$ & $\begin{array}{c}0.21 \\
(0.470) \\
\end{array}$ & $\begin{array}{l}1.13 * * * \\
(0.009) \\
\end{array}$ & $\begin{array}{l}1.50 * * \\
(0.029) \\
\end{array}$ & $\begin{array}{l}1.36^{* * *} \\
(0.014) \\
\end{array}$ \\
\hline$X_{t 3}$ & $\begin{array}{l}-0.56^{* * *} \\
(0.025) \\
\end{array}$ & $\begin{array}{l}-1.12 * * \\
(0.019) \\
\end{array}$ & $\begin{array}{c}0.10 \\
(0.645) \\
\end{array}$ & $\begin{array}{c}0.18 \\
(0.585) \\
\end{array}$ & $\begin{array}{c}-0.28 \\
(0.451) \\
\end{array}$ & $\begin{array}{l}0.68 * * \\
(0.015) \\
\end{array}$ \\
\hline$R_{t 3}$ & $\begin{array}{c}-0.09 * * * \\
(0.006)\end{array}$ & $\begin{array}{l}-0.12 * * \\
(0.012) \\
\end{array}$ & $\begin{array}{l}-0.07 * \\
(0.051) \\
\end{array}$ & $\begin{array}{l}-0.10^{* * *} \\
(0.028) \\
\end{array}$ & $\begin{array}{c}-0.06 \\
(0.316) \\
\end{array}$ & $\begin{array}{c}-0.19 * * * \\
(0.001) \\
\end{array}$ \\
\hline$A G_{t}$ & $\begin{array}{c}0.09 \\
(0.141)\end{array}$ & $\begin{array}{c}0.05 \\
(0.522)\end{array}$ & $\begin{array}{c}0.13 \\
(0.207)\end{array}$ & $\begin{array}{c}0.08 \\
(0.440)\end{array}$ & $\begin{array}{c}0.11 \\
(0.280)\end{array}$ & $\begin{array}{c}0.03 \\
(0.885)\end{array}$ \\
\hline$E P_{t-1}$ & $\begin{array}{c}-0.30 \\
(0.269)\end{array}$ & $\begin{array}{c}-0.88 \\
(0.108) \\
\end{array}$ & $\begin{array}{c}0.18 \\
(0.468) \\
\end{array}$ & $\begin{array}{c}0.51 \\
(0.217) \\
\end{array}$ & $\begin{array}{c}0.35 \\
(0.657) \\
\end{array}$ & $\begin{array}{c}0.89 * \\
(0.064) \\
\end{array}$ \\
\hline$D$ & $\begin{array}{c}-0.13 \\
(0.048) \\
\end{array}$ & $\begin{array}{l}-0.16^{*} \\
(0.098) \\
\end{array}$ & $\begin{array}{c}0.02 \\
(0.864) \\
\end{array}$ & $\begin{array}{c}-0.14 \\
(0.177) \\
\end{array}$ & $\begin{array}{c}-0.19 \\
(0.224) \\
\end{array}$ & $\begin{array}{c}0.07 \\
(0.654) \\
\end{array}$ \\
\hline$D * X_{t}$ & $\begin{array}{c}0.69 \\
(0.125) \\
\end{array}$ & $\begin{array}{l}2.24 * * \\
(0.030) \\
\end{array}$ & $\begin{array}{c}0.29 \\
(0.512) \\
\end{array}$ & $\begin{array}{c}0.74 \\
(0.270) \\
\end{array}$ & $\begin{array}{c}0.24 \\
(0.802) \\
\end{array}$ & $\begin{array}{c}0.60 \\
(0.481) \\
\end{array}$ \\
\hline$D * X_{t 3}$ & $\begin{array}{l}1.01 * * \\
(0.011)\end{array}$ & $\begin{array}{c}0.93 \\
(0.209) \\
\end{array}$ & $\begin{array}{c}0.59 \\
(0.101)\end{array}$ & $\begin{array}{c}0.58 \\
(0.184) \\
\end{array}$ & $\begin{array}{c}1.47 \\
(0.160)\end{array}$ & $\begin{array}{c}-0.08 \\
(0.809)\end{array}$ \\
\hline$D^{*} R_{t 3}$ & $\begin{array}{c}0.10 \\
(0.109)\end{array}$ & $\begin{array}{c}0.10 \\
(0.242)\end{array}$ & $\begin{array}{c}0.09 \\
(0.178)\end{array}$ & $\begin{array}{c}0.01 \\
(0.965) \\
\end{array}$ & $\begin{array}{c}0.02 \\
(0.849)\end{array}$ & $\begin{array}{c}-0.02 \\
(0.873) \\
\end{array}$ \\
\hline$D * A G_{t}$ & $\begin{array}{c}0.02 \\
(0.854) \\
\end{array}$ & $\begin{array}{c}0.03 \\
(0.763) \\
\end{array}$ & $\begin{array}{c}-0.03 \\
(0.808) \\
\end{array}$ & $\begin{array}{c}0.28 \\
(0.118) \\
\end{array}$ & $\begin{array}{c}0.23 \\
(0.358) \\
\end{array}$ & $\begin{array}{c}0.33 \\
(0.232) \\
\end{array}$ \\
\hline$D * E P_{t-1}$ & $\begin{array}{c}0.29 \\
(0.488)\end{array}$ & $\begin{array}{c}0.66 \\
(0.325)\end{array}$ & $\begin{array}{c}0.60 \\
(0.134)\end{array}$ & $\begin{array}{c}0.38 \\
(0.429)\end{array}$ & $\begin{array}{c}0.98 \\
0.3029 \\
\end{array}$ & $\begin{array}{l}-0.42 \\
(0.421)\end{array}$ \\
\hline Div & $\begin{array}{c}0.06 \\
(0.494) \\
\end{array}$ & $\begin{array}{l}-0.04 \\
(0.804) \\
\end{array}$ & $\begin{array}{c}0.18^{*} \\
(0.084) \\
\end{array}$ & $\begin{array}{c}-0.04 \\
(0.580) \\
\end{array}$ & $\begin{array}{c}-0.01 \\
(0.978) \\
\end{array}$ & $\begin{array}{c}-0.04 \\
(0.706) \\
\end{array}$ \\
\hline $\operatorname{Div}^{*} X_{t}$ & $\begin{array}{c}0.85^{*} \\
(0.075) \\
\end{array}$ & $\begin{array}{c}1.03 \\
(0.275) \\
\end{array}$ & $\begin{array}{l}1.05 * * \\
(0.036)\end{array}$ & $\begin{array}{c}0.90^{*} \\
(0.098) \\
\end{array}$ & $\begin{array}{c}2.15 \\
(0.023) \\
\end{array}$ & $\begin{array}{c}0.43 \\
(0.511) \\
\end{array}$ \\
\hline $\operatorname{Div}^{*} X_{t 3}$ & $\begin{array}{c}0.53 \\
(0.248) \\
\end{array}$ & $\begin{array}{c}1.08 \\
(0.390) \\
\end{array}$ & $\begin{array}{c}0.08 \\
(0.883) \\
\end{array}$ & $\begin{array}{c}0.32 \\
(0.370) \\
\end{array}$ & $\begin{array}{c}1.51 \\
(0.004) \\
\end{array}$ & $\begin{array}{c}-0.37 \\
(0.219) \\
\end{array}$ \\
\hline $\operatorname{Div}^{*} R_{t 3}$ & $\begin{array}{l}0.24 * * \\
(0.016) \\
\end{array}$ & $\begin{array}{l}0.33 * * \\
(0.044) \\
\end{array}$ & $\begin{array}{l}0.20 * * \\
(0.039) \\
\end{array}$ & $\begin{array}{c}0.04 \\
(0.402) \\
\end{array}$ & $\begin{array}{c}-0.02 \\
(0.775)\end{array}$ & $\begin{array}{l}0.14 * * \\
(0.029) \\
\end{array}$ \\
\hline$D i v * A G_{t}$ & $\begin{array}{l}-0.01 \\
(0.974)\end{array}$ & $\begin{array}{l}-0.19 \\
(0.692)\end{array}$ & $\begin{array}{c}0.40 \\
(0.149)\end{array}$ & $\begin{array}{c}0.07 \\
(0.510)\end{array}$ & $\begin{array}{c}0.01 \\
(0.935)\end{array}$ & $\begin{array}{c}0.11 \\
(0.604)\end{array}$ \\
\hline$D i v * E P_{t-1}$ & $\begin{array}{c}0.19 \\
(0.674) \\
\end{array}$ & $\begin{array}{c}-0.13 \\
(0.894) \\
\end{array}$ & $\begin{array}{c}0.79 \\
(0.229) \\
\end{array}$ & $\begin{array}{c}0.38 \\
(0.395) \\
\end{array}$ & $\begin{array}{c}0.55 \\
(0.528) \\
\end{array}$ & $\begin{array}{c}0.03 \\
(0.958) \\
\end{array}$ \\
\hline$D * D i v$ & $\begin{array}{c}0.05 \\
(0.661) \\
\end{array}$ & $\begin{array}{c}0.23 \\
(0.357) \\
\end{array}$ & $\begin{array}{l}-0.25^{*} \\
(0.088) \\
\end{array}$ & $\begin{array}{c}0.17 \\
(0.118) \\
\end{array}$ & $\begin{array}{c}0.19 \\
(0.250) \\
\end{array}$ & $\begin{array}{c}-0.01 \\
(0.930) \\
\end{array}$ \\
\hline$D * D i v * X_{t}$ & $\begin{array}{l}-2.02 * \\
(0.098) \\
\end{array}$ & $\begin{array}{l}-1.81 \\
(0.583) \\
\end{array}$ & $\begin{array}{c}-3.91 * * * \\
(0.001) \\
\end{array}$ & $\begin{array}{c}-0.90 \\
(0.254) \\
\end{array}$ & $\begin{array}{c}-1.90 \\
(0.136) \\
\end{array}$ & $\begin{array}{c}-0.55 \\
(0.566) \\
\end{array}$ \\
\hline$D * D_{i v} * X_{t 3}$ & $\begin{array}{c}-0.23 \\
(0.749) \\
\end{array}$ & $\begin{array}{c}1.68 \\
(0.332) \\
\end{array}$ & $\begin{array}{c}-1.00 \\
(0.184) \\
\end{array}$ & $\begin{array}{c}-0.40 \\
(0.404) \\
\end{array}$ & $\begin{array}{c}-1.79 \\
(0.113) \\
\end{array}$ & $\begin{array}{c}0.36 \\
(0.384)\end{array}$ \\
\hline$D * D i v * R_{t 3}$ & $\begin{array}{l}-0.23^{*} \\
(0.052)\end{array}$ & $\begin{array}{l}-0.40^{* *} \\
(0.037)\end{array}$ & $\begin{array}{l}-0.26 * * \\
(0.023)\end{array}$ & $\begin{array}{c}0.02 \\
(0.765)\end{array}$ & $\begin{array}{c}0.03 \\
(0.761)\end{array}$ & $\begin{array}{c}0.03 \\
(0.794)\end{array}$ \\
\hline$D * D i v * A G_{t}$ & $\begin{array}{c}0.47 \\
(0.251) \\
\end{array}$ & $\begin{array}{c}0.86 \\
(0.173)\end{array}$ & $\begin{array}{c}-0.41 \\
(0.227) \\
\end{array}$ & $\begin{array}{l}-0.34 * \\
(0.068) \\
\end{array}$ & $\begin{array}{c}-0.23 \\
(0.367)\end{array}$ & $\begin{array}{c}-0.42 \\
(0.144)\end{array}$ \\
\hline$D * D i v * E P_{t-1}$ & $\begin{array}{l}-2.15^{*} \\
(0.072) \\
\end{array}$ & $\begin{array}{l}-1.96 \\
(0.592) \\
\end{array}$ & $\begin{array}{c}-4.66 * * * \\
(0.001) \\
\end{array}$ & $\begin{array}{c}-0.88 \\
(0.096) \\
\end{array}$ & $\begin{array}{c}-1.42 \\
(0.186) \\
\end{array}$ & $\begin{array}{c}-0.14 \\
(0.814) \\
\end{array}$ \\
\hline Observations & 439 & 232 & 207 & 3064 & 1538 & 1526 \\
\hline $\mathrm{R}^{2}$ & 0.170 & 0.304 & 0.164 & 0.143 & 0.162 & 0.174 \\
\hline
\end{tabular}


Table 3 reports robustness results. The results for unprofitable and profitable firms are reported in columns (2) and (3), respectively. In each category, we report the results for the full sample, high growth firms and low growth firms. P-values are reported in parentheses. Returns, $R_{t}$, is calculated as buy-and-hold returns from eight months before the financial year-end to four months after the financial year-end. $R_{t 3}$ is the aggregated three years future returns. The earnings variable, $X_{t}$, is defined as earnings change per share deflated by the share price four months after the end of the financial year $t-1 . X_{t 3}$ is the aggregated three years future earnings change Earnings measure is the Worldscope item 01250 which is operating income before all exceptional items. $E P_{t-1}$ is defined as period $t-1$ 's earnings over price four months after the financial year-end of period $t-1$. $A G_{t}$ is the growth rate of total book value of assets for period $t$ (Datastream item 392). Firms with a disclosure score in the top (bottom) $50 \%$ of the distribution of disclosure scores are defined as high (low) disclosure firms. The dummy variable, $D$, is set equal to 1 ( 0 ) for high (low) disclosure firms. Dividends measure is dividends per share (Worldscope item 05101). The dummy variable, Div, is set equal to 1 (0) for firms that pay (not pay) dividends at the current year. High growth firms are defined as those having below median levels of BTMV, while low growth firms are defined as those having above median levels of BTMV. BTMV ratio is calculated as the inverse of the market to book value of equity ratio (Datastream item $M T B V$ ). The significance levels (two-tail test) are: $*=10$ per cent, $* *=5$ per cent, $* * *=1$ per cent. 